Check for updates

Cite this: Chem. Sci., 2017, 8, 6594

\section{Preparation and characterization of chemically bonded argon-boroxol ring cation complexes $\uparrow$}

\author{
Jiaye Jin, (D) Wei Li, Yuhong Liu, Guanjun Wang and Mingfei Zhou (DD* \\ The cation complexes $\left[\mathrm{ArB}_{3} \mathrm{O}_{4}\right]^{+},\left[\mathrm{ArB}_{3} \mathrm{O}_{5}\right]^{+},\left[\mathrm{ArB}_{4} \mathrm{O}_{6}\right]^{+}$and $\left[\mathrm{ArB}_{5} \mathrm{O}_{7}\right]^{+}$were prepared via a laser vaporization \\ supersonic ion source in the gas phase. Their vibrational spectra were measured via mass-selected infrared \\ photodissociation spectroscopy. Spectroscopy combined with quantum chemical calculations revealed \\ that the $\left[\mathrm{ArB}_{3} \mathrm{O}_{5}\right]^{+},\left[\mathrm{ArB}_{4} \mathrm{O}_{6}\right]^{+}$and $\left[\mathrm{ArB}_{5} \mathrm{O}_{7}\right]^{+}$cation complexes have planar structures each involving an \\ aromatic boroxol ring and an argon-boron covalent bond. In contrast, the $\left[\mathrm{ArB}_{3} \mathrm{O}_{4}\right]^{+}$cation is \\ characterized to be a weakly bound complex with a $\mathrm{B}_{3} \mathrm{O}_{4}{ }^{+}$chain structure.
}

Received 2nd June 2017 Accepted 17th July 2017

DOI: $10.1039 / \mathrm{c} 7 \mathrm{sc} 02472 \mathrm{j}$

rsc.li/chemical-science quite large binding energies (about 5-10 $\mathrm{kcal} \mathrm{mol}^{-1}$ ), but the electron density distribution analyses indicate that they have some dative bonding property instead of normal dative or electron-sharing covalent bonds. ${ }^{18}$

Significant efforts have also been made in searching for chemical bonding between argon and more challenging elements such as boron. Argon-boron containing compounds including $\mathrm{FArBO}, \mathrm{FArBF}_{2}$ and $\mathrm{FArBN}^{-}$were theoretically studied, and were predicted to be thermally metastable species with covalent Ar-B bonding. ${ }^{19}$ Argon coordination complexes including ArBBAr, $\mathrm{ArB}^{+}, \mathrm{ArBF}_{2}{ }^{+}$and $\mathrm{B}_{3} \mathrm{Ar}_{3}{ }^{+}$have also been studied computationally, ${ }^{20-23}$ and some of them exhibit remarkably strong Ar-B bonding. ${ }^{22,23}$ Only the $\mathrm{BAr}^{+}$and $\mathrm{ArBF}_{2}{ }^{+}$ cations as well as the metastable $\mathrm{ArBF}_{n}{ }^{2+}$ dications have been experimentally detected using mass spectrometry in the gas phase. $^{24,25}$ Here we report the experimental preparation of a group of boron oxide-argon cation complexes in the gas phase. Mass-selected infrared photodissociation spectroscopy and high-level quantum chemical calculation studies reveal strong argon-boron chemical bonding in these cation complexes featuring an aromatic boroxol ring.

\section{Experimental and theoretical methods}

The experiment was performed using a collinear tandem timeof-flight mass spectrometer equipped with a pulsed laser vaporization/supersonic expansion cluster ion source that was described in detail previously. ${ }^{26}$ The cation clusters were produced by pulsed laser $(532 \mathrm{~nm}$, Spectral Physics, $10 \mathrm{~Hz}$ repetition rate) ablation of a target made of ${ }^{10} \mathrm{~B}$-depleted or ${ }^{10} \mathrm{~B}$ enriched powders (Alfa Aesar, 90-97\%). The clusters were entrained by a helium carrier gas seeded with $0.1-1.0 \% \mathrm{O}_{2}$ and $5-10 \%$ argon at a backing pressure of $0.6-1.2 \mathrm{MPa}$ and underwent a supersonic expansion (General Valve Series 9) to form a collimated and cold molecular beam. The composition and cooling of the cation clusters were controlled by the time delay 
between the carrier gas pulse and the ablation laser. The cation clusters were extracted and analysed with a time-of-flight mass spectrometer (TOFMS). The ions of interest were mass selected, decelerated and then subjected to infrared photodissociation. The fragment ions together with the undissociated parent ions were reaccelerated and detected by a second collinear TOFMS. IR spectra were recorded by monitoring the relative yield of fragment ions as a function of the photodissociation IR laser wavelength. The infrared dissociation laser was generated by an OPO/OPA system (Laser Vision) pumped by a Continuum Surelite EX Nd:YAG laser, producing tunable infrared light with energies of $0.4-1.0 \mathrm{~mJ}$ per pulse in the wavelength range of 1150-2300 $\mathrm{cm}^{-1}$. The spectra were recorded by scanning the dissociation laser in steps of $2 \mathrm{~cm}^{-1}$ and averaging over 400 laser shots at each step.

The search for the global minimum structure of the $\left[\mathrm{ArB}_{3} \mathrm{O}_{4}\right]^{+},\left[\mathrm{ArB}_{3} \mathrm{O}_{5}\right]^{+},\left[\mathrm{ArB}_{4} \mathrm{O}_{6}\right]^{+}$and $\left[\mathrm{ArB}_{5} \mathrm{O}_{7}\right]^{+}$cation complexes and the bare $\left[\mathrm{B}_{x} \mathrm{O}_{y}\right]^{+}$cation clusters was performed at the B3LYP-D3/aug-cc-pVTZ ${ }^{27-29}$ level of theory using the Gaussian 09 program $^{30}$ with the empirical dispersion correction added to increase the accuracy on the long-range force. ${ }^{31}$ The lowest energy structures were then re-optimized at the $\operatorname{CCSD}(\mathrm{T}) / \mathrm{cc}$ pVTZ $^{32}$ level of theory using the MOLPRO 2010 program. $^{33}$

Chemical bonding analyses were performed by the adaptive natural density partitioning (AdNDP) method, ${ }^{34}$ quantum theory of atoms in molecules (QTAIM) ${ }^{35}$ and energy decomposition analysis with natural orbitals of chemical valence (EDANOCV).${ }^{36}$ AdNDP is a theoretical tool for obtaining patterns of chemical bonding based on the concept of the electron pair as the main element of chemical bonding models. It achieves seamless description of systems featuring both localized and delocalized bonding without invoking the concept of resonance. ${ }^{34}$ The AdNDP analyses were performed using the Multiwfn program. ${ }^{37}$ The wave function files generated from $\operatorname{CCSD}(\mathrm{T})$ calculations were employed to analyse the topology of the electron density with the AIMALL package. ${ }^{38}$ The critical points (atom, bond and ring), bond paths, and Laplace distribution of density provided a comprehensive view of the electron density between the boron and argon. The EDA-NOCV bonding was analysed at the $\mathrm{BP} 86 / \mathrm{TZ}^{2} \mathrm{P}^{39-41}$ level with the geometries optimized at the CCSD(T) level using the ADF2014.10 program package. ${ }^{42}$ The EDA-NOCV bonding analysis focuses on the instantaneous interaction energy, $\Delta E_{\text {int }}$, of a bond A-B between two fragments, $\mathrm{A}$ and $\mathrm{B}$, in the particular electronic reference state and in the frozen geometry of $\mathrm{AB}$. This $\Delta E_{\text {int }}$ is divided into three main components: the quasiclassical electrostatic interaction energy $\left(\Delta E_{\text {elstat }}\right)$, the Pauli repulsion energy $\left(\Delta E_{\text {Pauli }}\right)$ and the orbital interaction $\left(\Delta E_{\text {orb }}\right)$. The $\Delta E_{\text {orb }}$ accounts for the charge transfer and polarization effects, and is decomposed into contributions from each irreducible representation of the point group for the system.

\section{Results and discussion}

The mass spectrum using a ${ }^{10} \mathrm{~B}$-depleted boron target in expansions of helium gas seeded with oxygen in the $\mathrm{m} / \mathrm{z}$ range of 40-250 is shown in Fig. 1(a). The peaks due to ${ }^{11} \mathrm{~B}_{3} \mathrm{O}_{4}{ }^{+},{ }^{11} \mathrm{~B}_{3} \mathrm{O}_{5}{ }^{+}$,

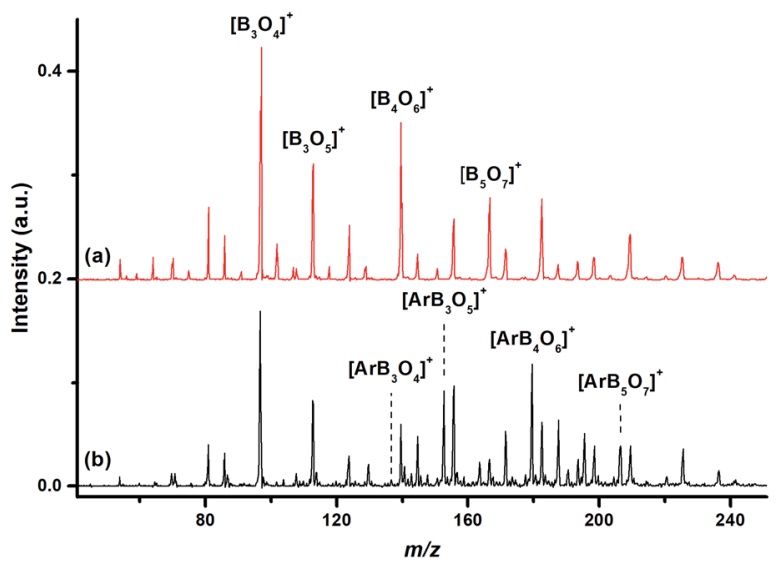

Fig. 1 Mass spectra of boron oxide cation clusters in the $m / z$ range of 40-250 produced by pulsed laser vaporization of a ${ }^{10} \mathrm{~B}$-depleted boron target in the expansion of (a) helium seeded with $1 \% \mathrm{O}_{2}$ (red line), and (b) helium seeded with $10 \%$ argon and $1 \% \mathrm{O}_{2}$ (black line).

${ }^{11} \mathrm{~B}_{4} \mathrm{O}_{6}{ }^{+}$and ${ }^{11} \mathrm{~B}_{5} \mathrm{O}_{7}^{+}$are the most intense peaks in the mass spectrum, in agreement with that reported in the literature. ${ }^{\mathbf{4 3}}$ Fig. 1(b) shows the mass spectrum under the same experimental conditions but with an additional $10 \%$ argon seeded in the expansion gas. The ${ }^{11} \mathrm{~B}_{3} \mathrm{O}_{4}{ }^{+}$ion remained the most intense peak, but the relative intensities of the ${ }^{11} \mathrm{~B}_{3} \mathrm{O}_{5}{ }^{+},{ }^{11} \mathrm{~B}_{4} \mathrm{O}_{6}{ }^{+}$and ${ }^{11} \mathrm{~B}_{5} \mathrm{O}_{7}^{+}$peaks were highly reduced. The $\left[\mathrm{Ar}^{11} \mathrm{~B}_{3} \mathrm{O}_{5}\right]^{+},\left[\mathrm{Ar}^{11} \mathrm{~B}_{4} \mathrm{O}_{6}\right]^{+}$ and $\left[\mathrm{Ar}^{11} \mathrm{~B}_{5} \mathrm{O}_{7}\right]^{+}$mass peaks were produced with quite high abundance. Similar spectra were produced using a ${ }^{10} \mathrm{~B}$-enriched target (Fig. S1 of ESI $\dagger$ ).

The $\left[\mathrm{Ar}^{11} \mathrm{~B}_{3} \mathrm{O}_{4}\right]^{+},\left[\mathrm{Ar}^{11} \mathrm{~B}_{3} \mathrm{O}_{5}\right]^{+},\left[\mathrm{Ar}^{11} \mathrm{~B}_{4} \mathrm{O}_{6}\right]^{+}$and $\left[\mathrm{Ar}^{11} \mathrm{~B}_{5} \mathrm{O}_{7}\right]^{+}$ cations were each mass-selected and subjected to infrared photodissociation. It was found that the $\left[\mathrm{Ar}^{11} \mathrm{~B}_{3} \mathrm{O}_{4}\right]^{+}$cation dissociated via losing the argon atom very efficiently and reached dissociation saturation at a quite low IR laser energy (about $0.5 \mathrm{~mJ}$ per pulse, see Fig. S2 $\dagger$ ). In contrast, the other ions dissociated with very low efficiency with the focused IR laser beam. As shown in Fig. $\mathrm{S} 2, \uparrow$ the dissociation efficiency only reached about 5-6\% at the highest available laser energy $(1.0 \mathrm{~mJ}$ per pulse) at $2062 \mathrm{~cm}^{-1}$ for $\left[\mathrm{Ar}^{11} \mathrm{~B}_{4} \mathrm{O}_{6}\right]^{+}$. These observations indicate that $\left[\mathrm{Ar}^{11} \mathrm{~B}_{3} \mathrm{O}_{4}\right]^{+}$is a weakly bound argon-tagged complex, ${ }^{44}$ while the $\left[\mathrm{Ar}^{11} \mathrm{~B}_{3} \mathrm{O}_{5}\right]^{+},\left[\mathrm{Ar}^{11} \mathrm{~B}_{4} \mathrm{O}_{6}\right]^{+}$and $\left[\mathrm{Ar}^{11} \mathrm{~B}_{5} \mathrm{O}_{7}\right]^{+}$ cations are more strongly bound. The infrared photodissociation spectra of these ions in the $1150-2300 \mathrm{~cm}^{-1}$ frequency region are shown in Fig. 2 . The $\left[\mathrm{Ar}^{11} \mathrm{~B}_{3} \mathrm{O}_{4}\right]^{+}$cation exhibited only two bands in the $2050-2150 \mathrm{~cm}^{-1}$ region, whereas three bands in the 1200-1700 $\mathrm{cm}^{-1}$ region were observed for the $\left[\mathrm{Ar}^{11} \mathrm{~B}_{3} \mathrm{O}_{5}\right]^{+}$ cation. The spectra of $\left[\mathrm{Ar}^{11} \mathrm{~B}_{4} \mathrm{O}_{6}\right]^{+}$and $\left[\mathrm{Ar}^{11} \mathrm{~B}_{5} \mathrm{O}_{7}\right]^{+}$in the 1200$1700 \mathrm{~cm}^{-1}$ region are quite similar to that of $\left[\mathrm{Ar}^{11} \mathrm{~B}_{3} \mathrm{O}_{5}\right]^{+}$, suggesting that $\left[\mathrm{Ar}^{11} \mathrm{~B}_{3} \mathrm{O}_{5}\right]^{+}$may be the core structure of $\left[\mathrm{Ar}^{11} \mathrm{~B}_{4} \mathrm{O}_{6}\right]^{+}$ and $\left[\mathrm{Ar}^{11} \mathrm{~B}_{5} \mathrm{O}_{7}\right]^{+}$. All of the bands were blue-shifted in the experiments using the ${ }^{10} \mathrm{~B}$-enriched target (see Fig. $\mathrm{S} 3 \dagger$ ). The observed frequency shifts (Table 1 ) with ${ }^{10} \mathrm{~B} /{ }^{11} \mathrm{~B}$ isotopic ratios in the range of 1.023-1.036 indicate that all of these bands are BO stretching vibrations. The bands above $2050 \mathrm{~cm}^{-1}$ are assigned as stretching vibrations of terminally bonded $\mathrm{B} \equiv \mathrm{O}$ fragments; the bands in the range of $1400-1700 \mathrm{~cm}^{-1}$ can be 


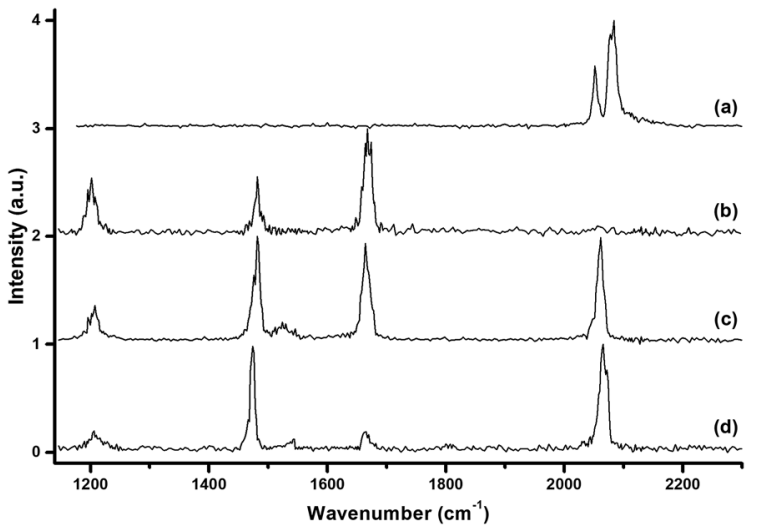

Fig. 2 The infrared photodissociation spectra of mass-selected cation clusters in the $1150-2300 \mathrm{~cm}^{-1}$ region measured by monitoring the argon photodissociation channel. (a) $\left[\mathrm{Ar}^{11} \mathrm{~B}_{3} \mathrm{O}_{4}\right]^{+}$, (b) $\left[\mathrm{Ar}^{11} \mathrm{~B}_{3} \mathrm{O}_{5}\right]^{+}$, (c) $\left[\mathrm{Ar}^{11} \mathrm{~B}_{4} \mathrm{O}_{6}\right]^{+}$, and (d) $\left[\mathrm{Ar}^{11} \mathrm{~B}_{5} \mathrm{O}_{7}\right]^{+}$.

Table 1 Experimental and calculated (B3LYP-D3/aug-cc-pVTZ, unscaled) infrared frequencies (in $\mathrm{cm}^{-1}$, the calculated IR intensities are listed in parentheses in $\left.\mathrm{km} \mathrm{mol}^{-1}\right)$ and isotopic shifts $\Delta\left(\mathrm{cm}^{-1}\right)$ of $\left[\mathrm{ArB}_{3} \mathrm{O}_{4}\right]^{+},\left[\mathrm{ArB}_{3} \mathrm{O}_{5}\right]^{+},\left[\mathrm{ArB}_{4} \mathrm{O}_{6}\right]^{+}$and $\left[\mathrm{ArB}_{5} \mathrm{O}_{7}\right]^{+}$

\begin{tabular}{|c|c|c|c|c|c|c|}
\hline & \multicolumn{3}{|c|}{ Exptl. } & \multicolumn{3}{|l|}{ Calcd } \\
\hline & ${ }^{11} \mathrm{~B}$ & ${ }^{10} \mathrm{~B}$ & $\Delta$ & ${ }^{11} \mathrm{~B}$ & ${ }^{10} \mathrm{~B}$ & $\Delta$ \\
\hline \multirow{3}{*}[\mathrm{ArB}_{3}\mathrm{O}_{4}]{$^{+}$} & & & & $2144.8(6)$ & 2217.1(6) & +72.8 \\
\hline & 2052 & 2120 & +68 & 2123.3(1868) & 2193(1770) & +69.9 \\
\hline & 2084 & 2138 & +54 & $2086.9(1135)$ & $2162.1(1135)$ & +75.2 \\
\hline \multirow[t]{4}{*}[\mathrm{ArB}_{3}\mathrm{O}_{5}]{$^{+}$} & 1668 & 1722 & +54 & $1681.7(684)$ & $1740.4(707)$ & +58.7 \\
\hline & & & & $1523.6(46)$ & $1582.3(47)$ & +58.7 \\
\hline & 1482 & 1536 & +54 & $1496.9(595)$ & $1548.4(663)$ & +51.5 \\
\hline & 1202 & 1230 & +28 & $1227.9(1119)$ & $1259.9(1186)$ & +32.0 \\
\hline \multirow{5}{*}[\mathrm{ArB}_{4}\mathrm{O}_{6}]{$^{+}$} & 2062 & 2132 & +70 & $2108.8(534)$ & $2181.6(596)$ & +72.8 \\
\hline & 1664 & 1724 & +60 & $1683.2(581)$ & $1742.1(604)$ & +58.9 \\
\hline & 1524 & 1574 & +50 & $1548.0(555)$ & $1601.5(495)$ & +53.5 \\
\hline & 1482 & 1528 & +46 & $1495.9(858)$ & $1546.7(1029)$ & +50.8 \\
\hline & 1208 & 1240 & +32 & $1234.5(1296)$ & $1269.2(1350)$ & +34.7 \\
\hline \multirow{6}{*}[\mathrm{ArB}_{5}\mathrm{O}_{7}]{$^{+}$} & 2066 & 2130 & +64 & $2114.4(808)$ & $2187.4(862)$ & +73.0 \\
\hline & & & & $2104.9(236)$ & $2177.7(250)$ & +72.8 \\
\hline & 1666 & 1722 & +56 & $1684.5(521)$ & $1743.5(544)$ & +59.0 \\
\hline & 1544 & 1598 & +54 & $1570.2(386)$ & $1623.3(401)$ & +53.1 \\
\hline & 1478 & 1522 & +44 & $1501.6(1824)$ & $1547.6(1968)$ & +46.0 \\
\hline & 1206 & 1244 & +38 & $1242.0(1478)$ & $1279.9(1485)$ & +37.9 \\
\hline
\end{tabular}

attributed to the vibrations of the aggregated boroxol ring, and the bands near $1200 \mathrm{~cm}^{-1}$ fall into the region of the stretching vibrations of $\mathrm{B}-\mathrm{O}$ single bonds. ${ }^{45}$

Quantum chemical calculations were carried out to investigate the geometric and electronic structures and the vibrational frequencies of the cation complexes. Fig. 3 shows the optimized geometries of the most stable structures of $\left[\mathrm{ArB}_{3} \mathrm{O}_{4}\right]^{+},\left[\mathrm{ArB}_{3} \mathrm{O}_{5}\right]^{+}$, $\left[\mathrm{ArB}_{4} \mathrm{O}_{6}\right]^{+}$and $\left[\mathrm{ArB}_{5} \mathrm{O}_{7}\right]^{+}$at the $\operatorname{CCSD}(\mathrm{T}) / \mathrm{cc}$-pVTZ level of theory. Geometric optimizations were also performed on various other possible structures at the B3LYP-D3/aug-cc-pVTZ level, and the results are shown in Fig. S4-S6. $\dagger$ The lowest-lying structure of $\left[\mathrm{ArB}_{3} \mathrm{O}_{4}\right]^{+}$was identified as having a ${ }^{1} \mathrm{~A}_{1}$ ground state with planar $C_{2 \mathrm{v}}$ symmetry involving a $\mathrm{B}_{3} \mathrm{O}_{4}$ chain and a weakly (a)

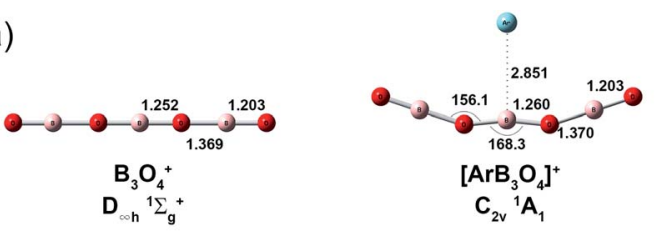

(b)
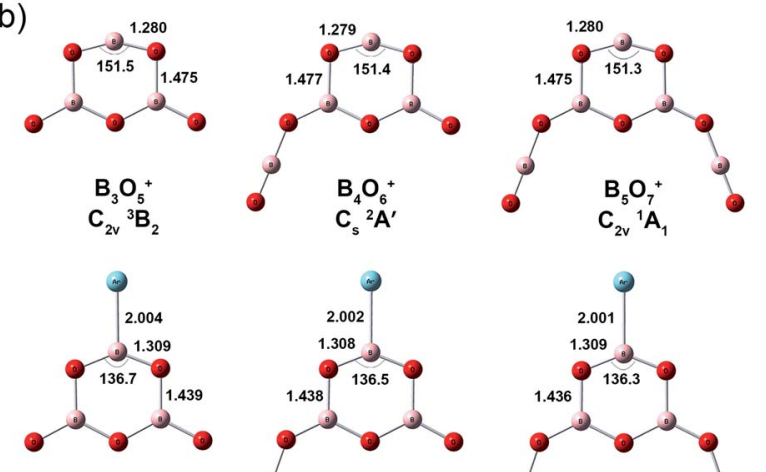

$\left[\mathrm{ArB}_{3} \mathrm{O}_{5}\right]^{+}$
$\mathrm{C}_{2 \mathrm{v}}{ }^{3} \mathrm{~B}_{2}$
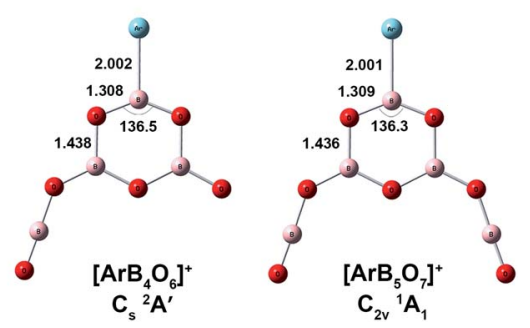

Fig. 3 Calculated geometries of the most stable structures of the $\left[\mathrm{ArB}_{3} \mathrm{O}_{4}\right]^{+},\left[\mathrm{ArB}_{3} \mathrm{O}_{5}\right]^{+},\left[\mathrm{ArB}_{4} \mathrm{O}_{6}\right]^{+}$and $\left[\mathrm{ArB}_{5} \mathrm{O}_{7}\right]^{+}$cation complexes and the bare $\left[\mathrm{B}_{3} \mathrm{O}_{4}\right]^{+},\left[\mathrm{B}_{3} \mathrm{O}_{5}\right]^{+},\left[\mathrm{B}_{4} \mathrm{O}_{6}\right]^{+}$and $\left[\mathrm{B}_{5} \mathrm{O}_{7}\right]^{+}$cations at the $\operatorname{CCSD}(\mathrm{T}) /$ cc-pVTZ level of theory. The bond lengths are in angstroms and the bond angles are in degrees.

tagging argon. The most stable structure of $\left[\mathrm{ArB}_{3} \mathrm{O}_{5}\right]^{+}$has a ${ }^{3} \mathrm{~B}_{2}$ ground state with planar $C_{2 \mathrm{v}}$ symmetry involving a boroxol ring. The argon atom is bound to one boron center of the boroxol ring, while the other two boron centers of the boroxol ring are each bonded by a monovalent $\mathrm{O}$ radical. The most stable structure of $\left[\mathrm{ArB}_{4} \mathrm{O}_{6}\right]^{+}$can be regarded as being formed via replacing an $\mathrm{O}$ radical of $\left[\mathrm{ArB}_{3} \mathrm{O}_{5}\right]^{+}$with an $\mathrm{OBO}$ fragment, resulting in a ${ }^{2} \mathrm{~A}^{\prime}$ ground state with planar $C_{\mathrm{s}}$ symmetry. The most stable structure of $\left[\mathrm{ArB}_{5} \mathrm{O}_{7}\right]^{+}$has a closed-shell singlet ground state with both $\mathrm{O}$ radicals of $\left[\mathrm{ArB}_{3} \mathrm{O}_{5}\right]^{+}$replaced by $\mathrm{OBO}$. It should be noted that there are conformational isomers for both $\left[\mathrm{ArB}_{4} \mathrm{O}_{6}\right]^{+}$and $\left[\mathrm{ArB}_{5} \mathrm{O}_{7}\right]^{+}$(see Fig. S5, $\uparrow$ structures $2 \mathrm{~A}$ and B for $\left[\mathrm{ArB}_{4} \mathrm{O}_{6}\right]^{+}$, and $3 \mathrm{~A}-\mathrm{C}$ for $\left.\left[\mathrm{ArB}_{5} \mathrm{O}_{7}\right]^{+}\right)$. These isomers are isoenergetic with similar infrared spectra (Fig. $\mathrm{S} 9$ and $\mathrm{S} 10 \dagger$ ). Thus, the experimentally observed cations may be due to mixtures of these conformational isomers. As shown in Table 1 and Fig. S7$\mathrm{S} 10, \dagger$ the calculated vibrational frequencies and boron isotopic shifts of the most stable structures for these cations were in quite good agreement with the experimental values.

The $\mathrm{Ar}-\mathrm{B}$ bond distances were predicted to be 2.004, 2.002 and $2.001 \AA$ for the $\left[\mathrm{ArB}_{3} \mathrm{O}_{5}\right]^{+},\left[\mathrm{ArB}_{4} \mathrm{O}_{6}\right]^{+}$and $\left[\mathrm{ArB}_{5} \mathrm{O}_{7}\right]^{+}$cation complexes, respectively, at the $\operatorname{CCSD}(\mathrm{T}) / \mathrm{cc}-\mathrm{pVTZ}$ level. These Ar$B$ bond distances are much shorter than the sum of the van der Waals radii of argon and boron $(\mathrm{Ar}+\mathrm{B}=1.88+2.08=3.96 \AA){ }^{46}$ and are close to the sum of their single-bond covalent radii $(\mathrm{Ar}+$ $\mathrm{B}=1.81 \AA$ ̊). ${ }^{47}$ This suggests strong interaction between argon and boron in these cation complexes. The Wiberg bond orders (Table 2) were predicted to be $0.543,0.545$ and 0.547 , respectively, slightly smaller than that of the H-Ar bond in HArF. ${ }^{18 a}$ 
Table 2 Energy decomposition analyses of $\left[\mathrm{ArB}_{3} \mathrm{O}_{4}\right]^{+},\left[\mathrm{ArB}_{3} \mathrm{O}_{5}\right]^{+}$, $\left[\mathrm{ArB}_{4} \mathrm{O}_{6}\right]^{+}$and $\left[\mathrm{ArB}_{5} \mathrm{O}_{7}\right]^{+}$at the BP86/TZ2P level using the CCSD(T)/CCpVTZ optimized geometries. The $\mathrm{Ar}-\mathrm{B}$ bond distances $(\AA)$, dissociation energies $\left(D_{\mathrm{e}}\right)$, natural charges $(Q)$ and Wiberg bond orders (WBI) are also shown. Energy values are given in $\mathrm{kcal} \mathrm{mol}^{-1}$

\begin{tabular}{lllll}
\hline Species & $\mathrm{Ar}_{-} \mathrm{B}_{3} \mathrm{O}_{4}{ }^{+}\left({ }^{1} \mathrm{~A}_{1}\right)$ & $\mathrm{Ar}-\mathrm{B}_{3} \mathrm{O}_{5}{ }^{+}\left({ }^{3} \mathrm{~B}_{2}\right)$ & $\mathrm{Ar}-\mathrm{B}_{4} \mathrm{O}_{6}{ }^{+}\left({ }^{2} \mathrm{~A}^{\prime}\right)$ & $\mathrm{Ar}_{-} \mathrm{B}_{5} \mathrm{O}_{7}+\left({ }^{+} \mathrm{A}_{1}\right)$ \\
$r(\mathrm{Ar}-\mathrm{B})$ & 2.851 & 2.004 & 2.002 & 2.001 \\
$D_{\mathrm{e}}$ & 3.4 & 16.2 & 16.3 & 16.4 \\
$\Delta E_{\text {int }}$ & -2.3 & -19.7 & -19.5 & -20.4 \\
$\Delta E_{\text {Pauli }}$ & 6.2 & 53.1 & 54.1 & 51.2 \\
$\Delta E_{\text {elstat }}{ }^{2}$ & $-1.6[18.8 \%]$ & $-15.0[20.7 \%]$ & $-16.1[21.9 \%]$ & $-14.3[20.0 \%]$ \\
$\Delta E_{\text {orb }}{ }^{a}$ & $-6.9[81.2 \%]$ & $-57.8[79.3 \%]$ & $-57.5[78.1 \%]$ & $-57.3[80.0 \%]$ \\
$\Delta E_{\text {orb }} \sigma^{b}$ & $-5.1(73.9 \%)$ & $-44.7(77.3 \%)$ & $-45.0(78.3 \%)$ & $-45.3(79.1 \%)$ \\
$\Delta E_{\text {orb }} \pi^{b}$ & & $-8.6(14.9 \%)$ & $-9.2(16.0 \%)$ & $-9.0(15.7 \%)$ \\
$\Delta E_{\text {orb}(\mathrm{r})}{ }^{b}$ & $-1.8(26.1 \%)$ & $-4.5(7.8 \%)$ & $-3.3(5.7 \%)$ & $-3.0(5.2 \%)$ \\
$Q(\mathrm{Ar})$ & 0.036 & 0.355 & 0.357 & 0.358 \\
WBI & 0.015 & 0.543 & 0.545 & 0.547
\end{tabular}

${ }^{a}$ The values in brackets give the percentage contribution to the total attractive interactions $\Delta E_{\text {elstat }}+\Delta E_{\text {orb }}{ }^{b}$ The values in parentheses give the percentage contribution to the total $\Delta E_{\text {orb }} . \Delta E_{\text {orb(r) }}$ is the rest interaction energy of $\Delta E_{\text {orb }}$.

The bond dissociation energies (Table 2) of the argon atom were 16.2, 16.3 and $16.4 \mathrm{kcal} \mathrm{mol}{ }^{-1}$ for $\left[\mathrm{ArB}_{3} \mathrm{O}_{5}\right]^{+},\left[\mathrm{ArB}_{4} \mathrm{O}_{6}\right]^{+}$and $\left[\mathrm{ArB}_{5} \mathrm{O}_{7}\right]^{+}$, respectively, at the $\mathrm{CCSD}(\mathrm{t}) / \mathrm{cc}-\mathrm{pVTZ}$ level, which are larger than that of the well-studied $\left[\mathrm{CH}_{3} \mathrm{Ar}\right]^{+}$complex. ${ }^{48}$ The $\mathrm{Ar}-$ $\mathrm{B}$ bond distance, Wiberg bond order and bond dissociation energy of the $\left[\mathrm{ArB}_{3} \mathrm{O}_{4}\right]^{+}$cation complex were predicted to be $2.851 \AA$, 0.015 and $3.4 \mathrm{kcal} \mathrm{mol}^{-1}$, indicating that the $\mathrm{Ar}-\mathrm{B}$ interaction in $\left[\mathrm{ArB}_{3} \mathrm{O}_{4}\right]^{+}$is much weaker than those in the $\mathrm{Ar}$ boroxol ring cation complexes.

Consistent with the large bond dissociation energies, the binding of the argon atom had a strong influence on the geometries of the $\mathrm{B}_{3} \mathrm{O}_{5}{ }^{+}, \mathrm{B}_{4} \mathrm{O}_{6}{ }^{+}$and $\mathrm{B}_{5} \mathrm{O}_{7}{ }^{+}$cation clusters. Large changes in the bond angles and lengths were observed in the boroxol ring upon argon bonding (Fig. 3 and S5 $\dagger$ ). The $\mathrm{O}-\mathrm{B}-\mathrm{O}$ angle of the argon coordinated OBO moiety was more acute and the two $\mathrm{B}-\mathrm{O}$ bonds were slightly longer, while the two adjacent O-B bonds were shorter than those of the bare $\mathrm{B}_{3} \mathrm{O}_{5}{ }^{+}, \mathrm{B}_{4} \mathrm{O}_{6}{ }^{+}$and $\mathrm{B}_{5} \mathrm{O}_{7}{ }^{+}$cation clusters. Fig. 4 shows a comparison between the

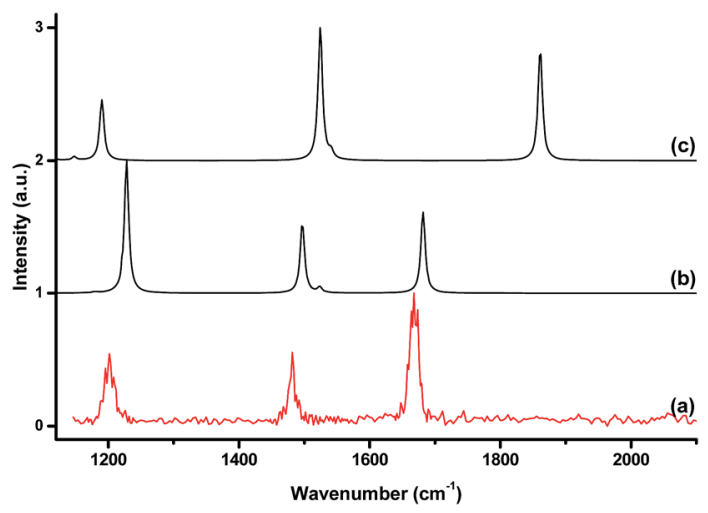

Fig. 4 The experimental IR spectrum of $\left[\mathrm{ArB}_{3} \mathrm{O}_{5}\right]^{+}$(a) and the simulated IR spectra of $\left[\mathrm{ArB}_{3} \mathrm{O}_{5}\right]^{+}$(b) and $\mathrm{B}_{3} \mathrm{O}_{5}{ }^{+}$(c) at the B3LYP-D3/augcc-pVTZ level. experimental IR spectrum of $\left[\mathrm{ArB}_{3} \mathrm{O}_{5}\right]^{+}$and the simulated IR spectra with and without argon bonding. It clearly shows that the argon bonding had a significant effect on the IR spectrum of $\left[\mathrm{B}_{3} \mathrm{O}_{5}\right]^{+}$, particularly on the antisymmetric stretching mode of the argon-coordinated OBO moiety, which was red-shifted by about $180 \mathrm{~cm}^{-1}$ upon argon bonding.

To understand the bonding in these cation complexes, AdNDP analysis was carried out (Fig. 5). This method has been successfully used to analyze chemical bonding in boron clusters, aromatic molecules and gold clusters. ${ }^{49}$ The analyses of $\left[\mathrm{ArB}_{3} \mathrm{O}_{5}\right]^{+},\left[\mathrm{ArB}_{4} \mathrm{O}_{6}\right]^{+}$and $\left[\mathrm{ArB}_{5} \mathrm{O}_{7}\right]^{+}$revealed one $2 \mathrm{c}-2 \mathrm{e} \sigma$ bond with an occupation number (ON) of 1.99 for each cation complex, which was formed between the in-plane $2 p$ atomic orbitals of the argon and boron. No such $\mathrm{Ar}-\mathrm{B}$ bond can be found in the $\left[\mathrm{ArB}_{3} \mathrm{O}_{4}\right]^{+}$cation complex with the chain structure. For each boroxol ring cation complex, there are three $3 \mathrm{c}-2 \mathrm{e}$ delocalized $\pi$ bonds within the boroxol ring, satisfying the $4 n+$

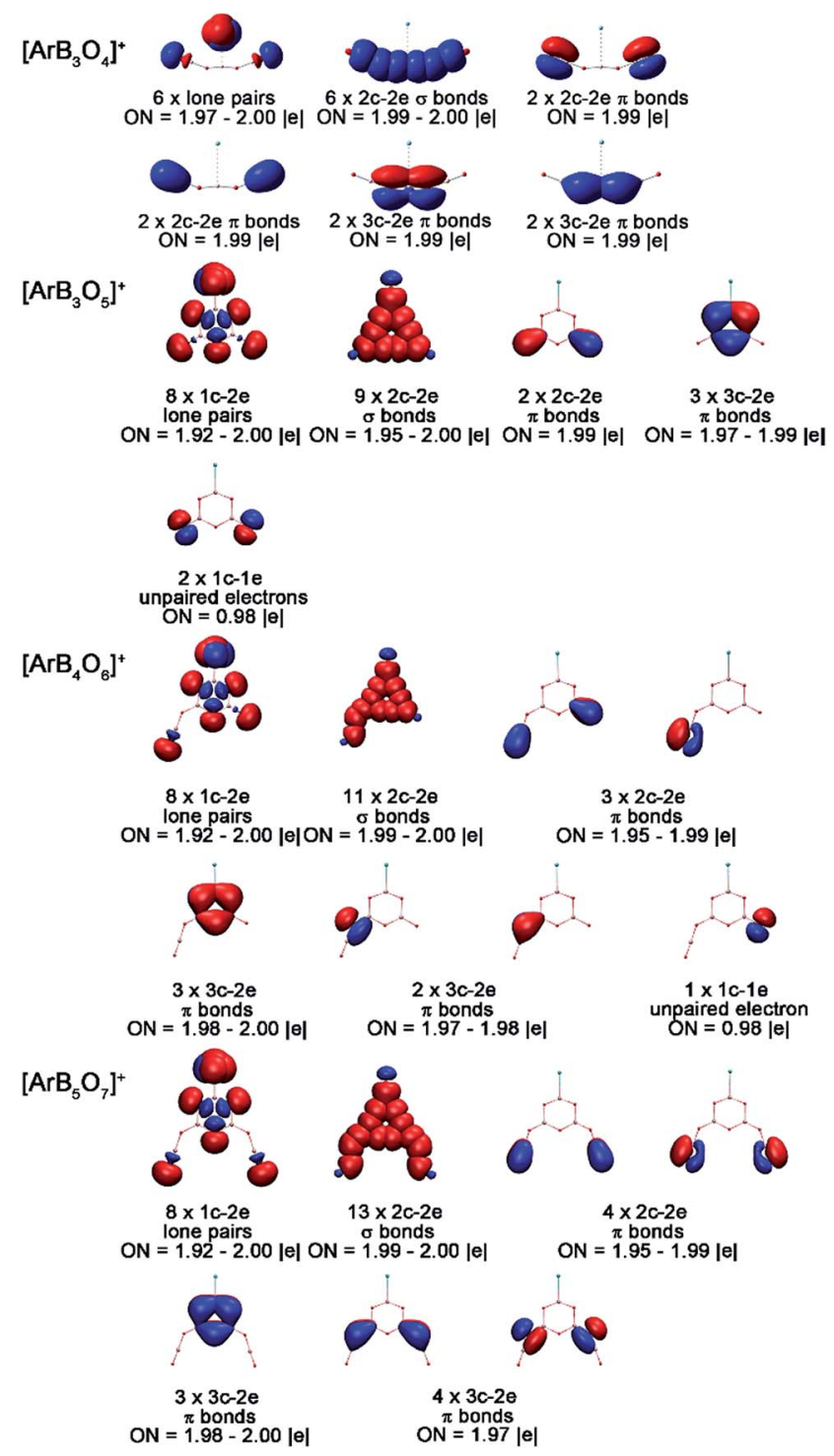

Fig. 5 AdNDP bonding orbitals of the $\left[\mathrm{ArB}_{3} \mathrm{O}_{4}\right]^{+},\left[\mathrm{ArB}_{3} \mathrm{O}_{5}\right]^{+},\left[\mathrm{ArB}_{4} \mathrm{O}_{6}\right]^{+}$ and $\left[\mathrm{ArB}_{5} \mathrm{O}_{7}\right]^{+}$cation complexes. ON stands for occupation number. 
2 rule for aromaticity, similar to the $\mathrm{B}_{4} \mathrm{O}_{4}{ }^{+}$cations reported previously. ${ }^{50}$ Thus, all three boroxol ring cation clusters are $\pi$ aromatic.

We investigated the topology of the electron density distribution of the species using the quantum theory of atoms in molecules (QTAIM) method. ${ }^{35}$ Fig. 6 shows the Laplacian of the electron density $\left(\nabla^{2} \rho(r)\right)$ of the cation complexes in the molecular plane (the side view is shown in Fig. S11 $\dagger$ ). There is a bond critical point $\left(\nabla \rho(r)=0\right.$ and $\nabla^{2} \rho(r)<0$ in one direction $)$ and an associated bond path for the Ar-B moiety in each cation complex. The Laplacian electron density distribution clearly shows a depletion region $\left(\nabla^{2} \rho(r)>0\right)$ between argon and boron in $\left[\mathrm{ArB}_{3} \mathrm{O}_{4}\right]^{+}$and charge concentration "islands" $\left(\nabla^{2} \rho(r)<0\right.$, red dashed lines) between boron and argon in the boroxol ring complexes, suggesting a noncovalent $\mathrm{Ar}-\mathrm{B}$ interaction in $\left[\mathrm{ArB}_{3} \mathrm{O}_{4}\right]^{+}$and a genuine $\mathrm{Ar}-\mathrm{B}$ dative bond in the boroxol ring cation complexes. Natural bond orbital analysis indicated that the argon atom carries positive charges of around $0.36 e$ in the argon-boroxol ring species, but positive charges of only $0.04 e$ in $\left[\mathrm{ArB}_{3} \mathrm{O}_{4}\right]^{+}$(Table 2).

The nature of the Ar-B interactions was further analyzed with the EDA-NOCV method, ${ }^{36}$ which gave detailed insight into the bonding situation. The numerical results of the Ar-B interactions are listed in Table 2 . It is quite obvious that the orbital interactions came mainly from the $\sigma$ donation of argon to the positively charged boron center, which contributes $73.9 \%$ of the orbital energy $\left(\Delta E_{\text {orb }}\right)$ in $\left[\mathrm{ArB}_{3} \mathrm{O}_{4}\right]^{+}, 77.3 \%$ in $\left[\mathrm{ArB}_{3} \mathrm{O}_{5}\right]^{+}$, $78.3 \%$ in $\left[\mathrm{ArB}_{4} \mathrm{O}_{6}\right]^{+}$, and $79.1 \%$ in $\left[\mathrm{ArB}_{5} \mathrm{O}_{7}\right]^{+}$. The contribution of the $\pi$ donation was much weaker than the $\sigma$ donation. Fig. 7 displays the deformation densities $\Delta \rho(\sigma)$ which are connected to the $\sigma$ donation interactions (the plots of deformation densities of $\pi$ orbital interaction are given in Fig. S12 $\dagger$ ). The color code for the charge flow is red to blue. The shape of the deformation density for $\left[\mathrm{ArB}_{3} \mathrm{O}_{4}\right]^{+}$implies that the orbital

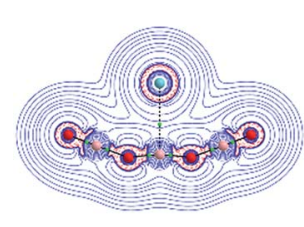

$\left[\mathrm{ArB}_{3} \mathrm{O}_{4}\right]^{+}$

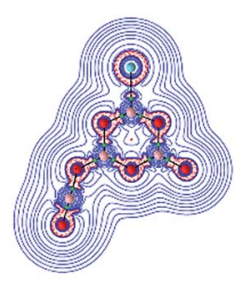

$\left[\mathrm{ArB}_{4} \mathrm{O}_{6}\right]^{+}$

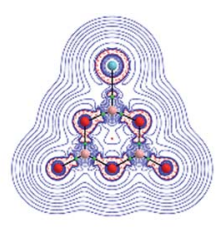

$\left[\mathrm{ArB}_{3} \mathrm{O}_{5}\right]^{+}$

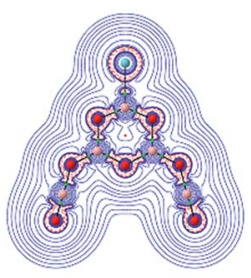

$\left[\mathrm{ArB}_{5} \mathrm{O}_{7}\right]^{+}$
Fig. 6 Contour diagrams of the Laplacian of the electron density $\left(\nabla^{2} \rho(r)\right)$ of $\left[\mathrm{ArB}_{3} \mathrm{O}_{4}\right]^{+},\left[\mathrm{ArB}_{3} \mathrm{O}_{5}\right]^{+},\left[\mathrm{ArB}_{4} \mathrm{O}_{6}\right]^{+}$and $\left[\mathrm{ArB}_{5} \mathrm{O}_{7}\right]^{+}$in the molecular plane. The black sticks represent the bond path (BP), and tiny green points illustrate the bond critical point (BCP). The dashed red lines indicate areas of charge concentration $\left(\nabla^{2} \rho(r)<0\right)$ while solid blue lines show areas of charge depletion $\left(\nabla^{2} \rho(r)>0\right)$.
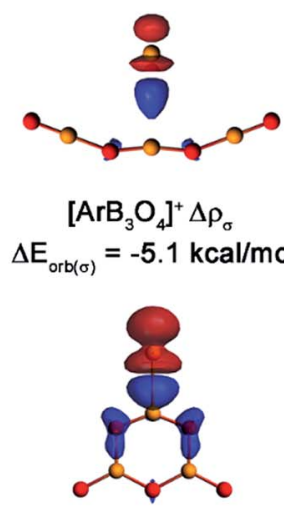

$$
\begin{gathered}
{\left[\mathrm{ArB}_{3} \mathrm{O}_{5}\right]^{+} \Delta \rho_{\sigma}} \\
\Delta \mathrm{E}_{\text {orb }(\sigma)}=-44.7 \mathrm{kcal} / \mathrm{mol}
\end{gathered}
$$

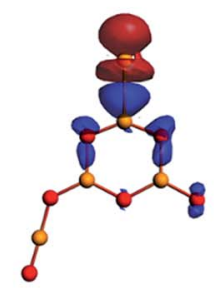

$\left[\mathrm{ArB}_{4} \mathrm{O}_{6}\right]^{+} \Delta \rho_{\sigma}$

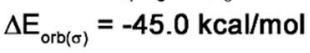

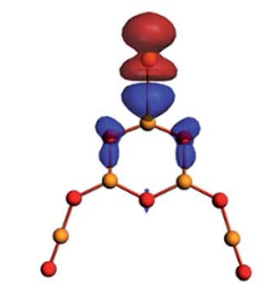

$\left[\mathrm{ArB}_{5} \mathrm{O}_{7}\right]^{+} \Delta \boldsymbol{\rho}_{\sigma}$

$\Delta \mathrm{E}_{\mathrm{orb}(\sigma)}=-45.3 \mathrm{kcal} / \mathrm{mol}$
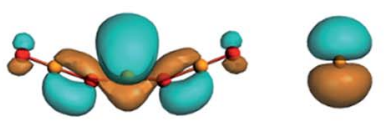

$$
\begin{array}{cc}
\mathrm{B}_{3} \mathrm{O}_{4}{ }^{+} \mathrm{LUMO} & \text { Ar HOMO } \\
(-9.2 \mathrm{eV}) & (-10.4 \mathrm{eV})
\end{array}
$$

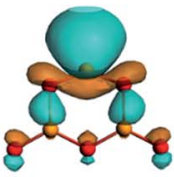

$\mathrm{B}_{3} \mathrm{O}_{5}^{+} \mathrm{LUMO}$

$(-11.2 \mathrm{eV})$
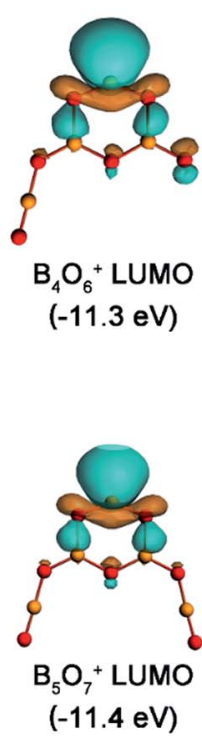

Fig. 7 Plots of the deformation densities $\Delta \rho$ (isocontour 0.002 a.u.) of the pairwise $\sigma$ orbital interactions between the argon and boron oxide cations in the $\left[\mathrm{ArB}_{3} \mathrm{O}_{4}\right]^{+},\left[\mathrm{ArB}_{3} \mathrm{O}_{5}\right]^{+},\left[\mathrm{ArB}_{4} \mathrm{O}_{6}\right]^{+}$and $\left[\mathrm{ArB}_{5} \mathrm{O}_{7}\right]^{+}$cations and the pairwise interaction orbitals, the LUMO of bare cations and $\mathrm{HOMO}$ of the argon atom. The orbital interaction energies and the fragments' orbital energies were calculated at the BP86/TZ2P level. The charge flow of the $\sigma$ orbital interactions is red to blue.

interaction only caused the charge transfer from argon to the region between argon and boron. This kind of interaction can be considered as an ion-induced weak dipole interaction, as reported previously. ${ }^{18 a}$ The shapes of the deformation densities for the $\left[\mathrm{ArB}_{3} \mathrm{O}_{5}\right]^{+},\left[\mathrm{ArB}_{4} \mathrm{O}_{6}\right]^{+}$and $\left[\mathrm{ArB}_{5} \mathrm{O}_{7}\right]^{+}$cations indicate that the charge flow comes mainly from the in-plane lone-pair electrons at argon to the $\mathrm{BO}_{2}$ moiety of the boroxol ring, which leads to charge accumulation at the boron atom and the two adjacent $\mathrm{O}-\mathrm{B}$ bonds (blue region). Note that the interaction energies $\left(\Delta E_{\text {int }}\right)$ and the orbital energies $\left(\Delta E_{\text {orb }}\right)$ of the $\left[\mathrm{ArB}_{3} \mathrm{O}_{5}\right]^{+}$, $\left[\mathrm{ArB}_{4} \mathrm{O}_{6}\right]^{+}$and $\left[\mathrm{ArB}_{5} \mathrm{O}_{7}\right]^{+}$cation complexes were smaller than those of the strongly covalent $\mathrm{H}$-Ar bond in HArF, but were much larger than those of the $[\mathrm{ArB}]^{+}$cation, which has been characterized as involving weak bonding interaction with some 
covalent or electrostatic properties. ${ }^{18 a}$ Fig. 7 also displays the pairwise interaction orbitals, the lowest unoccupied molecular orbitals (LUMOs) of bare cations and the highest occupied molecular orbital (HOMO) of argon. Although the LUMO of $\mathrm{B}_{3} \mathrm{O}_{4}{ }^{+}$exhibits very similar spatial distribution to those of the boroxol ring cations, it lies 1.2 and about $2.0 \mathrm{eV}$ higher in energy than the HOMO of argon $(-10.4 \mathrm{eV})$ and the LUMO of the boroxol ring cations $(-11.2$ to $-11.4 \mathrm{eV})$, respectively. This leads to a much weaker donation interaction in $\left[\mathrm{ArB}_{3} \mathrm{O}_{4}\right]^{+}$than those in $\left[\mathrm{ArB}_{3} \mathrm{O}_{5}\right]^{+},\left[\mathrm{ArB}_{4} \mathrm{O}_{6}\right]^{+}$, and $\left[\mathrm{ArB}_{5} \mathrm{O}_{7}\right]^{+}$.

\section{Conclusions}

Boron oxide-argon cation complexes in the form of $\left[\mathrm{ArB}_{3} \mathrm{O}_{4}\right]^{+}$, $\left[\mathrm{ArB}_{3} \mathrm{O}_{5}\right]^{+},\left[\mathrm{ArB}_{4} \mathrm{O}_{6}\right]^{+}$and $\left[\mathrm{ArB}_{5} \mathrm{O}_{7}\right]^{+}$were prepared in the gas phase and were mass-selected and studied by infrared photodissociation spectroscopy. Spectroscopy combined with quantum chemical calculations revealed that the $\left[\mathrm{ArB}_{3} \mathrm{O}_{4}\right]^{+}$ cation is a weakly bound Ar-tagged complex with a $\mathrm{B}_{3} \mathrm{O}_{4}{ }^{+}$chain structure. In contrast, the $\left[\mathrm{ArB}_{3} \mathrm{O}_{5}\right]^{+},\left[\mathrm{ArB}_{4} \mathrm{O}_{6}\right]^{+}$and $\left[\mathrm{ArB}_{5} \mathrm{O}_{7}\right]^{+}$ cations all have planar structures each involving an aromatic boroxol ring and an argon-boron covalent bond. The $\left[\mathrm{ArB}_{3} \mathrm{O}_{5}\right]^{+}$, $\left[\mathrm{ArB}_{4} \mathrm{O}_{6}\right]^{+}$and $\left[\mathrm{ArB}_{5} \mathrm{O}_{7}\right]^{+}$cations reported here represent the very first examples of spectroscopically characterized complexes featuring strong dative bonding between argon and boron that are stable in the gas phase.

\section{Acknowledgements}

The work was financially supported by the National Natural Science Foundation of China (grant no. 21688102) and the Ministry of Science and Technology of China (2013CB834603 and 2012YQ220113-3).

\section{Notes and references}

1 (a) N. Bartlett, Proc. Chem. Soc., 1962, 6, 218; (b) H. H. Howard, H. Selig and J. G. Malm, J. Am. Chem. Soc., 1962, 84, 3593; (c) R. Hope, W. Dähne, W. Rödder and H. Mattauch, Angew. Chem., 1962, 74, 903.

2 K. O. Christe, Angew. Chem., Int. Ed., 2001, 40, 1419-1421.

3 R. B. Gerber, Annu. Rev. Phys. Chem., 2004, 55, 55-78.

4 W. Grochala, Chem. Soc. Rev., 2007, 36, 1632-1655.

5 L. Khriachtchev, M. Räsänen and R. B. Gerber, Acc. Chem. Res., 2009, 42, 183-191.

6 (a) P. Pyykkö, Phys. Scr., 1990, T33, 52-53; (b) R. Lindh, W. P. Kraemer and M. Kämper, J. Phys. Chem. A, 1999, 103, 8295-8302; (c) A. Cohen, J. Lundell and R. B. Gerber, J. Chem. Phys., 2003, 119, 6415-6417.

7 (a) L. Khriachtchev, M. Pettersson, N. Runeberg, J. Lundell and M. Räsänen, Nature, 2000, 406, 874-876; (b) G. Frenking, Nature, 2000, 406, 836-837.

8 N. Runeberg, M. Pettersson, L. Khriachtchev, J. Lundell and M. Räsänen, J. Chem. Phys., 2001, 114, 836-841.

9 M. J. Barlow, B. M. Swinyard, P. J. Owen, J. Cernicharo, H. L. Gomez, R. J. Ivison, O. Krause, T. L. Lim,
M. Matsuura, S. Miller, G. Olofsson and E. T. Polehampton, Science, 2013, 342, 1343-1345.

10 (a) C. A. Thompson and L. Andrews, J. Am. Chem. Soc., 1994, 116, 423-424; (b) G. Frenking, W. Koch, J. Gauss and D. Cremer, J. Am. Chem. Soc., 1988, 110, 8007-8016; (c) A. Veldkamp and G. Frenking, Chem. Phys. Lett., 1994, 226, 11-16.

11 (a) Q. Wang and X. F. Wang, J. Phys. Chem. A, 2013, 117, 1508-1513; (b) Q. N. Zhang, M. H. Chen, M. F. Zhou, D. M. Andrada and G. Frenking, J. Phys. Chem. A, 2015, 119, 2543-2552; (c) R. Saha, S. Pan, G. Merino and P. K. Chattaraj, J. Phys. Chem. A, 2015, 119, 6746-6752.

12 (a) R. N. Perutz and J. J. Turner, J. Am. Chem. Soc., 1975, 97, 4791-4800; (b) J. R. Wells and E. Weitz, J. Am. Chem. Soc., 1992, 114, 2783-2787.

13 (a) C. J. Evans and M. C. L. Gerry, J. Chem. Phys., 2000, 112, 1321-1329; (b) C. J. Evans and M. C. L. Gerry, J. Chem. Phys., 2000, 112, 9363-9374; (c) C. J. Evans, A. Lesarri and M. C. L. Gerry, J. Am. Chem. Soc., 2000, 122, 6100-6105; (d) C. J. Evans, D. S. Rubinoff and M. C. L. Gerry, Phys. Chem. Chem. Phys., 2000, 2, 3943-3948.

14 (a) X. F. Wang, L. Andrews, F. Brosi and S. Riedel, Chem.-Eur. J., 2013, 19, 1397-1409; (b) X. F. Wang, L. Andrews, K. Willmann, F. Brosi and S. Riedel, Angew. Chem., Int. Ed., 2012, 51, 10628-10632.

15 (a) Y. Y. Zhao, Y. Gong and M. F. Zhou, J. Phys. Chem. A, 2006, 110, 10777-10782; (b) Y. Y. Zhao, Y. Gong, M. H. Chen and M. F. Zhou, J. Phys. Chem. A, 2006, 110, 1845-1849; (c) Y. Y. Zhao and M. F. Zhou, Sci. China: Chem., 2010, 53, 327-336.

16 (a) J. Li, B. E. Bursten, B. Y. Liang and L. Andrews, Science, 2002, 295, 2242-2245; (b) B. Y. Liang, L. Andrews, J. Li and B. E. Bursten, Inorg. Chem., 2004, 43, 882-894; (c) L. Andrews, B. Y. Liang, J. Li and B. E. Bursten, J. Am. Chem. Soc., 2003, 125, 3126-3139.

17 A. Shayeghi, R. L. Johnston, D. M. Rayner, R. Schäfer and A. Fielicke, Angew. Chem., Int. Ed., 2015, 54, 10675-10680.

18 (a) W. L. Zou, D. Nori-Shargh and J. E. Boggs, J. Phys. Chem. A, 2013, 117, 207-212; (b) D. Himmel, I. Krossing and A. Schnepf, Angew. Chem., Int. Ed., 2014, 53, 370-374; (c) G. Frenking, Angew. Chem., Int. Ed., 2014, 53, 6040-6046; D. Himmel, I. Krossing and A. Schnepf, Angew. Chem., Int. Ed., 2014, 53, 6047-6048.

19 (a) T. Y. Lin, J. B. Hsu and W. P. Hu, Chem. Phys. Lett., 2005, 402, 514-518; (b) J. L. Chen, C. Y. Yang, H. J. Lin and W. P. Hu, Phys. Chem. Chem. Phys., 2013, 15, 9701-9709; (c) W. Chen, G. H. Chen, D. Wu and Q. Wang, Phys. Chem. Chem. Phys., 2016, 18, 17534-17545; (d) P. Antoniotti, S. Borocci, N. Bronzolino, P. Cecchi and F. Grandinetti, J. Phys. Chem. A, 2007, 111, 10144-10151; (e) A. Sirohiwal, D. Manna, A. Ghosh, T. Jayasekharan and T. K. Ghanty, J. Phys. Chem. A, 2013, 117, 10772-10782; (f) A. Ghosh, S. Dey, D. Manna and T. K. Ghanty, J. Phys. Chem. A, 2015, 119, 5732-5741.

20 A. Papakondylis, E. Miliordos and A. Mavridis, J. Phys. Chem. A, 2004, 108, 4335-4340. 
21 (a) A. Ding, J. Karlau, J. Weise, J. Kendrick, P. J. Kuntz, I. H. Hillier and M. F. Guest, J. Phys. Chem., 1978, 68, 2206-2213; (b) G. Frenking, W. Koch, D. Cremer, J. Gauss and J. F. Liebman, J. Chem. Phys., 1989, 93, 3410-3418; (c) M. W. Wong and L. Radom, J. Chem. Phys., 1989, 93, 63036308; (d) J. P. Harris, A. M. Gardner, T. G. Wright, W. H. Breckenridge and L. A. Viehland, J. Phys. Chem. A, 2012, 116, 4995-5007.

22 Z. Lv, G. H. Chen, D. Li, D. Wu, X. C. Huang, Z. R. Li and W. G. Liu, J. Chem. Phys., 2011, 134, 154302.

23 R. Saha, S. Pan, S. Mandal, M. Orozco, G. Merino and P. K. Chattaraj, RSC Adv., 2016, 6, 78611-78620.

24 J. T. Koskinen, J. Phys. Chem. A, 1999, 103, 9565-9568.

25 (a) L. Levee, C. Calogero, E. Barbieri, S. Byrne, C. Donahue, M. Eisenberg, S. Hattenbach, J. Le, J. F. Capitani, J. Roithová and D. Schröder, Int. J. Mass Spectrom., 2012, 323, 2-7; (b) F. Grandinetti, Eur. J. Mass Spectrom., 2011, 17, 423-463.

26 G. J. Wang, C. X. Chi, X. P. Xing, C. F. Ding and M. F. Zhou, Sci. China: Chem., 2014, 57, 172-177.

27 A. D. Becke, J. Chem. Phys., 1993, 98, 5648-5652.

28 C. T. Lee, W. T. Yang and R. G. Parr, Phys. Rev. B: Condens. Matter Mater. Phys., 1988, 37, 785-789.

29 (a) T. H. Dunning, J. Chem. Phys., 1989, 90, 1007-1023; (b) D. E. Woon and T. H. Dunning, J. Chem. Phys., 1993, 98, 1358-1371.

30 M. J. Frisch, G. W. Trucks, H. B. Schlegel, G. E. Scuseria, M. A. Robb, J. R. Cheeseman, G. Scalmani, V. Barone, B. Mennucci, G. A. Petersson, H. Nakatsuji, M. Caricato, X. Li, H. P. Hratchian, A. F. Izmaylov, J. Bloino, G. Zheng, J. L. Sonnenberg, M. Hada, M. Ehara, K. Toyota, R. Fukuda, J. Hasegawa, M. Ishida, T. Nakajima, Y. Honda, O. Kitao, H. Nakai, T. Vreven, J. A. Montgomery Jr, J. E. Peralta, F. Ogliaro, M. Bearpark, J. J. Heyd, E. Brothers, K. N. Kudin, V. N. Staroverov, T. Keith, R. Kobayashi, J. Normand, K. Raghavachari, A. Rendell, J. C. Burant, S. S. Iyengar, J. Tomasi, M. Cossi, N. Rega, J. M. Millam, M. Klene, J. E. Knox, J. B. Cross, V. Bakken, C. Adamo, J. Jaramillo, R. Gomperts, R. E. Stratmann, O. Yazyev, A. J. Austin, R. Cammi, C. Pomelli, J. W. Ochterski, R. L. Martin, K. Morokuma, V. G. Zakrzewski, G. A. Voth, P. Salvador, J. J. Dannenberg, S. Dapprich, A. D. Daniels, O. Farkas, J. B. Foresman, J. V. Ortiz, J. Cioslowski, and D. J. Fox, Gaussian 09, Revision D.01, Gaussian, Inc., Wallingford CT, 2013.

31 S. Grimme, S. Ehrlich and L. Goerigk, J. Comput. Chem., 2011, 32, 1456-1465.

32 P. J. Knowles, C. Hampel and H. J. Werner, J. Chem. Phys., 1993, 99, 5219.
33 H.-J. Werner, P. J. Knowles, G. Knizia, F. R. Manby, M. Schütz, P. Celani, W. Györffy, D. Kats, T. Korona, R. Lindh, A. Mitrushenkov, G. Rauhut, K. R. Shamasundar, T. B. Adler, R. D. Amos, A. Bernhardsson, A. Berning, D. L. Cooper, M. J. O. Deegan, A. J. Dobbyn, F. Eckert, E. Goll, C. Hampel, A. Hesselmann, G. Hetzer, T. Hrenar, G. Jansen, C. Köppl, Y. Liu, A. W. Lloyd, R. A. Mata, A. J. May, S. J. McNicholas, W. Meyer, M. E. Mura, A. Nicklass, D. P. O’Neill, P. Palmieri, D. Peng, K. Pflüger, R. Pitzer, M. Reiher, T. Shiozaki, H. Stoll, A. J. Stone, R. Tarroni, T. Thorsteinsson and M. Wang, MOLPRO, version 2010.1.

34 D. Y. Zubarev and A. I. Boldyrev, Phys. Chem. Chem. Phys., 2008, 10, 5207-5217.

35 R. F. W. Bader, Chem. Rev., 1991, 91, 893-928.

36 M. P. Mitoraj, A. Michalak and T. Ziegler, J. Chem. Theory Comput., 2009, 5, 962-975.

37 T. Lu and F. W. Chen, J. Comput. Chem., 2012, 33, 580-592. 38 A. K. Todd, AIMAll Version 16.10.31, TK Gristmill Software, Overland Park KS, USA, 2016, http://aim.tkgristmill.com.

39 A. D. Becke, Phys. Rev. A, 1988, 38, 3098-3100.

40 J. P. Perdew, Phys. Rev. B: Condens. Matter Mater. Phys., 1986, 33, 8822-8824.

41 E. Van Lenthe and E. J. Baerends, J. Comput. Chem., 2003, 24, 1142.

42 (a) G. te Velde, F. M. Bickelhaupt, E. J. Baerends, C. F. Guerra, S. J. A. Van Gisbergen, J. G. Snijders and T. Ziegler, J. Comput. Chem., 2001, 22, 931-967; (b) ADF2014, SCM, Theoretical Chemistry, Vrije Universiteit, Amsterdam, The Netherlands, http://www.scm.com.

43 R. J. Doyle, J. Am. Chem. Soc., 1988, 110, 4120-4126.

44 (a) K. R. Asmis, Phys. Chem. Chem. Phys., 2012, 14, 92709281; (b) A. M. Ricks, Z. E. Reed and M. A. Duncan, J. Phys. Chem. A, 2003, 107, 7396-7405.

45 (a) T. R. Burkholder and L. Andrews, J. Chem. Phys., 1991, 95, 8697-8709; (b) F. A. Miller and C. H. Wilkins, Anal. Chem., 1952, 24, 1253-1294; (c) Y. Gong and M. F. Zhou, J. Phys. Chem. A, 2008, 112, 5670-5675.

46 C. E. Housecroft and A. G. Sharpe, Inorganic Chemistry, Pearson/Prentice Hall, Essex, UK, 3rd edn, 2008.

47 P. Pyykkö and M. Atsumi, Chem.-Eur. J., 2009, 15, 186-197. 48 (a) R. V. Olkhov, S. A. Nizkorodov and O. Dopfer, J. Chem. Phys., 1998, 108, 10046-10060; (b) R. W. Gora, S. Roszak and J. Leszczynski, J. Chem. Phys., 2001, 115, 771-777.

49 (a) D. Y. Zubarev and A. I. Boldyrev, J. Org. Chem., 2008, 73, 9251-9258; (b) D. Y. Zubarev and A. I. Boldyrev, J. Phys. Chem. A, 2009, 113, 866-868.

50 T. Ou, W. J. Tian, X. R. You, Y. J. Wang, K. Wang and H. J. Zhai, Phys. Chem. Chem. Phys., 2015, 17, 29697-29706. 